
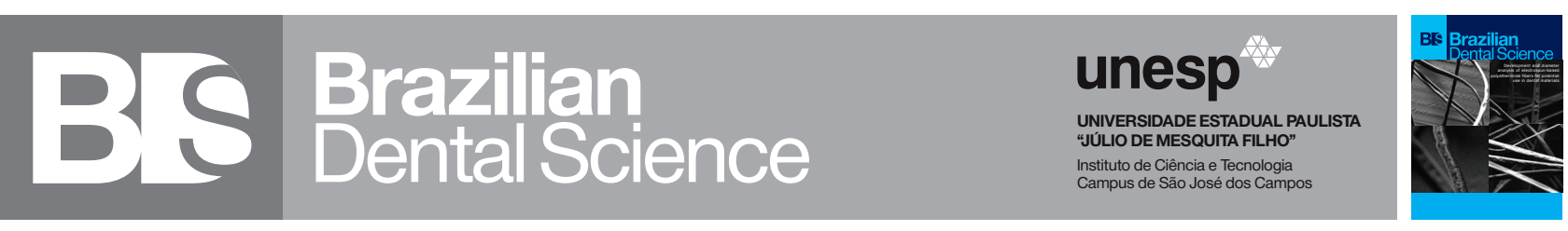

\title{
Retreatment of 6 Ceramic Restorations In A Single Session - The Application of Er:YAG Laser And CAD/CAM Technology: An 1 Year Follow Up Clinical Evaluation
}

Retratamento de 6 restaurações de cerâmica em uma única sessão - Utilizando o Laser ER:YAG e a tecnologia CAD/ CAM com Acompanhamento de 1 ano

Christian BERNAL ${ }^{1}$, Ester Mi Ryoung LEE ${ }^{1}$, Carlos de Paula EDUARDO ${ }^{1}$, Ana Maria Aparecida SOUZA ${ }^{1}$, Luciane Hiramatsu AZEVEDO ${ }^{1}$ 1 - School of Dentistry, University of São Paulo, São Paulo, SP, Brazil.

\section{ABSTRACT}

Background: To present the benefits of high power lasers (Er: YAG and Nd: YAG) over the use of the high speed turbine for the extraction of ceramics restorations, without damaging the surfaces of the teeth; being a relatively easier and faster procedure without the use of anesthetic agents, and the preparation of the ceramic restorations and cementing in the single session; with a follow-up of 1 year. Objective: The benefits of lasers over high-speed turbine mechanical instrumentation for crown removal encompass efficient restoration recovery without damage to tooth surfaces; and a relatively easier and faster procedure without the use of anesthetic agents. Methods: The Er: YAG laser (no contact; 3.2-4.0 W, $20 \mathrm{~Hz}$ ) was used to extract the porcelain prosthesis, followed by a gingivectomy with the Nd: YAG laser on tooth 12 to improve the gingival contour. The dental surfaces where the ceramic prosthesis will be cemented were scanned. Then, CAD / CAM technology was used to make the ceramic veneers that were cemented in the same session. Results: The efficacy the Er:YAG laser energy was observed by the decreased of the time to remove all-ceramic materials through ablation of bonding cements, reducing working time by $75 \%$ compared to a high-speed turbine. Conclusions: An Er: YAG laser can safely remove lithium disilicate crowns with the

\section{RESUMO}

Antecedentes: Apresentar os benefícios dos lasers de alta potência (Er: YAG e Nd:YAG) sobre o uso da turbina de alta velocidade para a remoção de restaurações cerâmicas, sem danificar as superfícies dos dentes; sendo um procedimento relativamente mais fácil e rápido evitando o uso de agentes anestésicos, conseguindo fazer o preparo das restaurações de cerâmica e cimentação em uma única sessão; com seguimento de 1 ano. Objetivo: Os benefícios dos lasers sobre a instrumentação mecânica com turbina de alta velocidade para a remoção da coroa abrangem a recuperação eficiente da restauração sem danos às superfícies dos dentes; e um procedimento relativamente mais fácil e rápido sem o uso de agentes anestésicos. Métodos: O laser Er: YAG (sem contato; 3,2-4,0 W, $20 \mathrm{~Hz}$ ) foi utilizado para remover a prótese de porcelana, seguido de gengivectomia com o laser Nd: YAG no dente 12 para melhorar o contorno gengival. As superfícies dentais onde a prótese de cerâmica será cimentada foram escaneadas. Em seguida, a tecnologia CAD / CAM foi utilizada para confeccionar as facetas de cerâmicas que foram cimentadas na mesma sessão. Resultados: A eficácia da energia do laser Er: YAG foi observada pela diminuição do tempo na remoção dos materiais cerâmicos por meio da ablação dos cimentos de ligação, reduzindo o tempo de trabalho em $75 \%$ em relação a uma turbina de alta velocidade. Conclusão: Um laser Er: YAG pode remover com segurança as coroas de dissilicato de lítio com as configurações usadas neste estudo. A remoção 
settings used in this study. Laser-assisted removal of all ceramic PDFs is a promising treatment protocol. The use of the Nd: YAG (2.0 W power, short $20 \mathrm{~Hz}, 320 \mu \mathrm{m}$ optical fiber, in contact) laser allowed gingivoplasty to be performed, automatically cauterizing avoiding post-operative bleeding, and facilitating the preparation of ceramic restorations the same day. The use of high-power lasers and the use of accompanying CAD / CAM technology allowed this clinical case to be completed in a single visit without the use of temporary restorations, achieving absolute patient satisfaction.

\section{KEYWORDS}

Er:YAG; Nd:YAG; Lithium disilicate ceramic; CAD/CAM. assistida por laser de todos os PDFs de cerâmica é um protocolo de tratamento promissor. O uso do laser Nd: YAG $(2,0 \mathrm{~W}$ potência, curta $20 \mathrm{~Hz}, 320 \mu \mathrm{m}$ fibra ótica, em contato) permitiu a realização da gengivoplastia, cauterizando automaticamente evitando sangramento pós-operatório e facilitando o preparo das restaurações cerâmicas no mesmo dia. O uso de lasers de alta potência e o uso da tecnologia CAD / CAM que o acompanha permitiram que este caso clínico fosse concluído em uma única visita, sem o uso de restaurações temporárias, alcançando a satisfação absoluta do paciente.

\section{PALAVRAS-CHAVE}

Er:YAG; Nd:YAG; Disilicato de Litio; CAD/ CAM.

\section{INTRODUCTION}

$\mathrm{T}$ he demand of patients for the replacement of ceramic restorations in anterior teeth, for different reasons such as color change, inadequate shape, fracture and others, is a current challenge for the dentist [1-3].

The challenge is currently in the process of removing ceramic restorations, as there is a concern regarding damage to the dental structure, caused by the increase in intrapulpal temperature generated by the friction of the high speed drill, cutting time of the Ceramic restoration and wear of the remnescent structure, which provide patient discomfort $[1,2,4]$.

Currently, laser technology offers us a fast and effective alternative to remove ceramic restorations, the Erbium (Er: YAG) laser acts selectively on the contents of the adhesive interface, vaporizing the water molecules and resinous monomers [4,5], making it possible to reduce the working time by $75 \%$ compared to a high-powered drill, controlling the increase in intra-pulp temperature if the appropriate parameters were used $[3,6]$, thus avoiding unnecessary wear on the dental structure, and decreasing patient discomfort [7].

$\mathrm{CAD} / \mathrm{CAM}$ is a digital technology in continuing development that allow dentists to work with no laboratory step, by scanning of the surface, building a digital modeling, reducing session time, eliminating the steps of making provisional crowns [8-11].

The objective of this report is to explain the process of removal and replacement by color change of 6 ceramic restorations (from canine to canine), following a step-by-step technique, beginning with the removal of ceramic restorations with the Er: YAG laser, neodymiumdoped yttrium aluminum garnet (Nd:YAG) laser gingivoplasty, dental preparation, preparation of ceramic restorations with CAD / CAM technology, and cementation of ceramic restorations in a single session, followed by follow-up after one year, showing the maintenance of the result satisfactory. 


\section{CASE REPORT}

A 55-year-old patient received dental treatment with indirect restorations 10 years ago, 5 years ago she decided to modify them because she was not satisfied with the result. (Figure 1)

The patient comes to the consultation still unsatisfied by the appearance of the restorations, her concern lies in their aesthetics; specifically, in the tone of the porcelains, which are slightly grayish and stained, and the format of the teeth. The patient did not seek treatment previously, as she was not comfortable removing all crowns with the conventional method, which would take an average of 45 minutes per tooth with a highspeed turbine, the patient did not want to use temporary prostheses again while waiting for the definitive prostheses, which made her desist from doing the treatment several times.

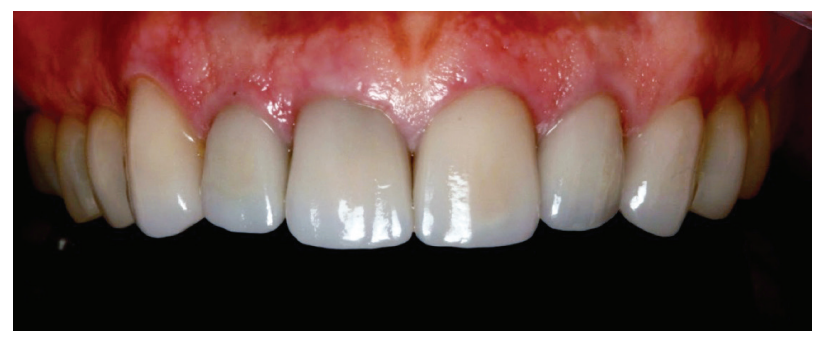

Figure 1 - Case initial.

\section{Removal of the ceramic restorations}

The Er: YAG laser (LightWalker, ATSM0215AF / 1S, Ljubljana Slovenia) associated with the H02N handpiece in non-contact mode (Figure 2), was used at a $14-16 \mathrm{~mm}$ distance, $0.9 \mathrm{~mm}$ spot size at the focal point, was used for the removal of the ceramic restoration, with a power of 3.2 W, $20 \mathrm{~Hz}$ frequency, super short pulse mode (SSP), the irradiation temperature control was performed with water / air in a 4/4 ratio and then the power increased to $4.0 \mathrm{~W}$, keeping the frequency at $20 \mathrm{~Hz}[12,13]$. (Table I)
Table I - Case initial

$\begin{array}{ccccccc}\text { Laser } & \begin{array}{l}\text { Wave- } \\ \text { length }\end{array}\end{array}$ Frequency $\begin{gathered}\text { Spot } \\ \text { size }\end{gathered}$ Power Energy $\begin{gathered}\begin{array}{c}\text { Energy } \\ \text { density }\end{array} \\ \text { Er:YAG }\end{gathered}$

The total time for the extraction of the 6 ceramic restorations was 90 minutes in total, with an average of 15 minutes per restoration removed (Figure 3). The ablation process with the Er: YAG laser that will cause the ceramic restoration to fall occurs by the selective absorption of light at the level of the resinous cement that contains easily vaporizable components such as water and residual monomers, which after their explosive vaporization due to as they change in volume when melting, they produce a hydrodynamic ejection. We must be careful when using the highpower laser because it generates heat, which could increase the intrapulpal temperature to more than $5.5^{\circ} \mathrm{C}$, which would produce irreversible damage to the tooth, so we must have protocols and defined parameters such as that we use in this case report, and thus avoid complications $[4,13]$. We then decided to perform a gingivectomy on the right lateral incisor to improve the gingival contour, using an Nd: YAG laser, $1064 \mathrm{~nm}$ (LightWalker ATSM021-5AF / 1S, Ljubljana Slovenia), $2.0 \mathrm{~W}$ power, short pulse mode (SP), $20 \mathrm{~Hz}$ frequency, $320 \mu \mathrm{m}$ optical fiber, in contact (Table II) (Figure 4).

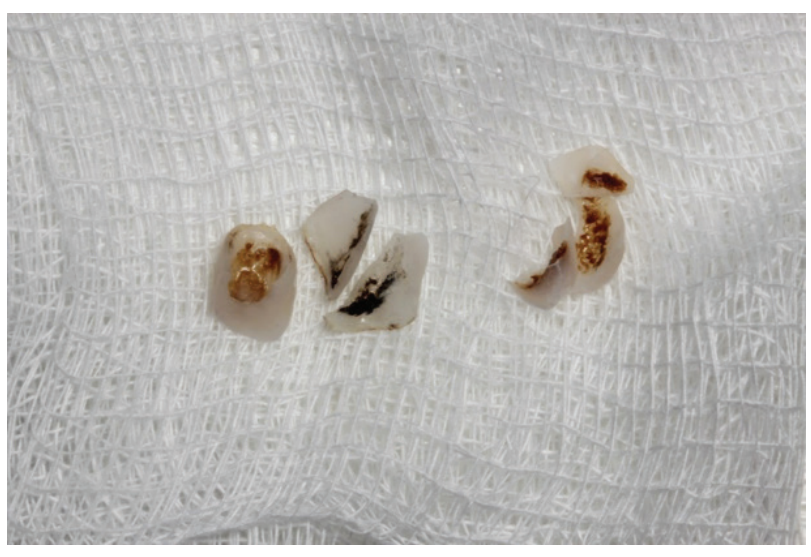

Figure 2 - Crowns removed with laser Er:YAG. 


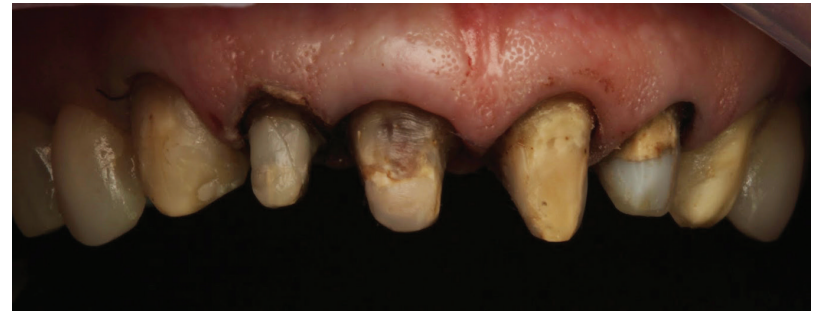

Figure 3 - Gingivectomy in teeth 1.2 with Nd:YAG Laser and polishing of all preparations

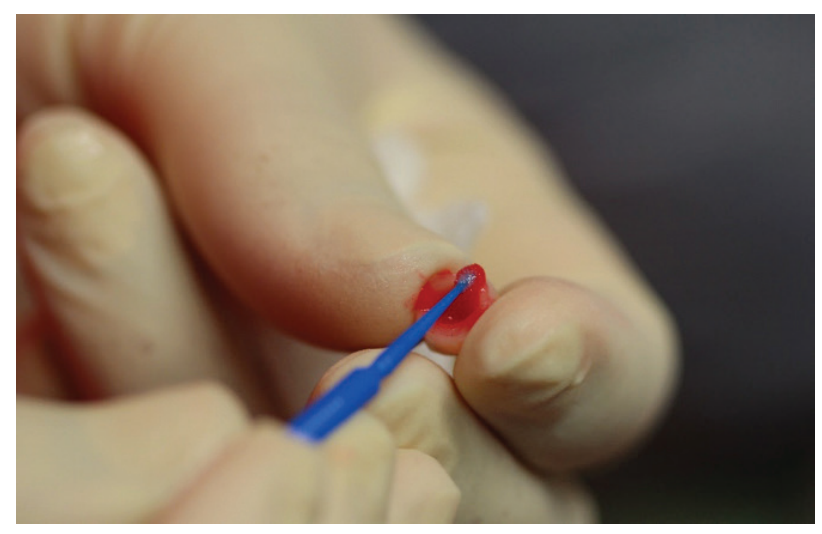

Figure 4 - Application in the internal surface of hydrofluoric acid

Table II - Laser parameter considered for gengivectomy with $\mathrm{Nd}: Y A G$

\begin{tabular}{|cccccccc} 
Laser & $\begin{array}{c}\text { Wave- } \\
\text { length }\end{array}$ & $\begin{array}{c}\text { Frequency } \\
\text { Diam- } \\
\text { eter }\end{array}$ & Power & Energy & $\begin{array}{c}\text { Energy } \\
\text { density }\end{array}$ \\
\hline Nd:YAG & $1064 \mathrm{~nm}$ & $20 \mathrm{~Hz}$ & $320 \mathrm{um}$ & $2 \mathrm{~W}$ & $0,1 \mathrm{~J}$ & $\begin{array}{c}124,40 \\
\mathrm{~J} / \mathrm{cm}^{2}\end{array}$
\end{tabular}

\section{Scanning and prosthetic steps}

Aftertheceramicrestorationswereremoved, the prepared teeth were simultaneously polished and digitized (Figure 3) using an intraoral scanner (CEREC Omnicam ${ }^{\circledR}$, DentsplySirona Bensheim, Germany). After obtaining the digital molding of the dental preparations, the design of the indirect restorations was carried out by the Cerec Premium SW 4.5 software, respecting a minimum thickness for the milling of the restorations. Starting from the design of the ceramic restorations, milling was performed with pre-sintered lithium disilicate ceramic blocks (IPS e.max CAD, Ivoclar Vivadent,
Shaan, Liechtenstein) on the MCXL $^{\circledR}$ milling machine (DentsplySirona Bensheim, Germany) [14-16] . After the milling process, the ceramic crystallization was carried out for 15 minutes at an initial temperature of $500^{\circ}$, gradually increasing to $850^{\circ}$ Celsius, later the ceramic restoration was hand-stained, in order to obtain a more natural result. This procedure was carried out for a period of 5 minutes, to later place the ceramic restorations in the oven for 15 minutes again; finally, glaze was applied and baked for 15 more minutes, thus obtaining the final ceramic restoration [17].

\section{Preparation and cementing of ceramic veneers}

After preparation, the ceramic restorations were placed on the dental substrate with the cement test system (Panavia V5, Kuraray Noritake Dental, Tokyo, Japan), in order to test and verify the most satisfactory cement color for cementation. final. After cement selection and approval by the patient, the ceramic restorations were installed. The internal surfaces of the pieces were conditioned with hydrofluoric acid (Porcelain Etchant 9.5\%, Bisco Inc.) for 20 seconds (Figure 5). The surfaces were then washed with water, blown dry and then conditioned with $37 \%$ phosphoric acid (FGM) for 60 seconds and finally washed and dried again. Shortly after, they were silanized with Clearfil Ceramic Primer adhesive (Kuraray Noritake Dental, Tokyo, Japan) [18].

Once the pieces were prepared, the preparation of the dental surfaces began. Teeth were isolated with rubber dam ((K-Dent, Minas Gerais, Brasil) and cleaned with a pumice stone, rinsed with water, and blown dry. Conditioning with 37\% phosphoric acid (FGM, São Paulo, Brasil) was carried out, for 30 seconds on enamel and 15 seconds on dentin, again it was washed and dried. The bonding agent was then applied, which was light-cured for 40 seconds. Light-curing resin cement (Panavia V5, Kuraray Noritake Dental, Tokyo, Japan) was used (Figure 
6). After cementation, the excess cement was removed and the pieces were photopolymerized for 20 seconds on each face (Figure 7). [3,7]

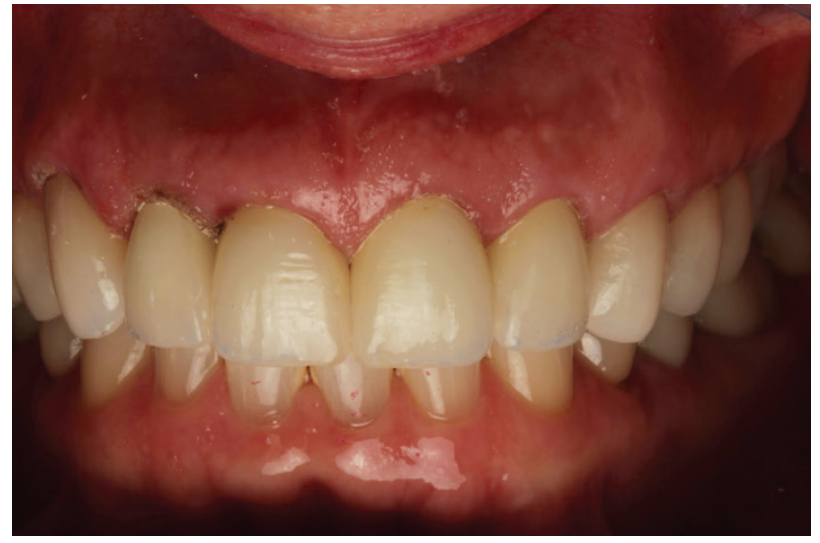

Figure 5 - Post cementation without cleaning excess resinous cement.

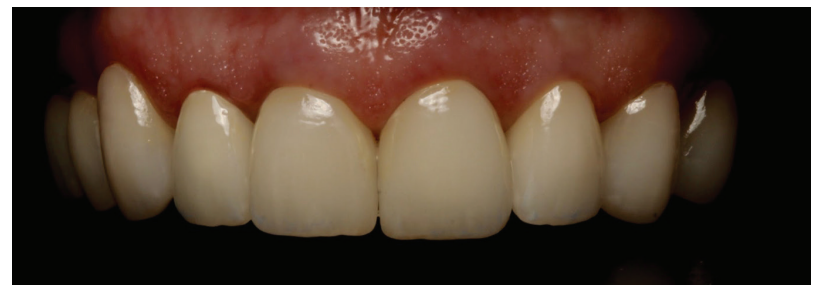

Figure 6 - Case finalized.

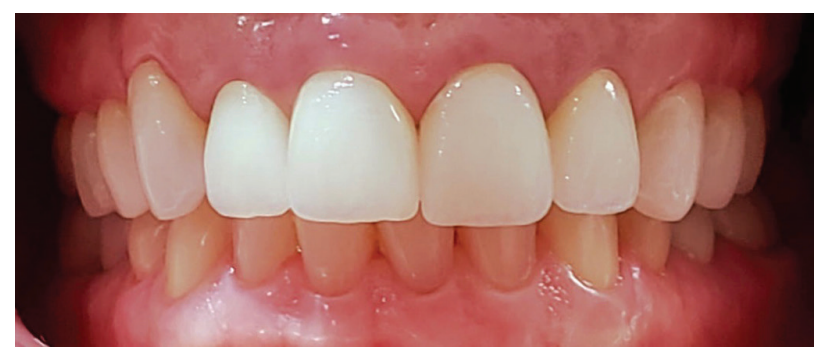

Figure 7 - Case finished.

\section{DISCUSSION}

The demand for the use of aesthetic ceramic restorations increases every year and there is a growing concern for the longevity of indirect restorations, trying to avoid the causes of the failure of these restorations. [1,2,7,14$16]$.
Porcelain veneers for dental use have undergone in recent years a significant improvement in the aesthetic and mechanical qualities of resistance and maintenance of gloss and color $[15,16]$. The development of new ceramic structures provided thinner and stronger facets and even better aesthetic qualities [15]. This was important because many treatments required very little wear or, in other cases, no wear was necessary.

However, failures can occur in the indication, selection of materials, types of preparation, molding techniques, failure of cementation, finishing, occlusal adjustment and case follow-up [1,5,11]; all of these steps must be followed carefully. In this report, the patient's complaint was related to the color of the cemented porcelains. The translucency of the porcelain allowed the color of the teeth (endodontically treated) to show the gray structure of the dentin structure.

The use of the Er: YAG laser associated with adequate parameters found in the literature, allowed us to eliminate unsatisfactory ceramic restorations, reducing working time by $75 \%$ compared to traditional methods such as manual crown extractors or burs; providing comfort, speed and protection of the remaining substrate [16]. In the same way, the use of the Er: YAG laser associated with adequate parameters will avoid an increase in intrapulpal temperature, which could cause irreversible damage such as pulp necrosis, unlike the $\mathrm{CO}_{2}$ and Nd: YAG laser $[1,12]$, which produce an increase in intrapulpal temperature because its absorption is slower than Er: YAG [12], therefore it will produce more heat.

In the literature we observe that the parameters of the Er: YAG laser for the removal of ceramic restorations vary depending on the type and thickness of this, as well as the substrate to which it was cemented, since a ceramic restoration cemented in dentin will 
be easier to remove compared to a ceramic restoration cemented in enamel, and this is due to the presence of humidity in the dentin that makes the bond strength weaker $[1,2,6]$.

The parameters used in our case report are based on other parameters used in different case reports and in vitro studies, which were adapted taking into account the substrate in which we would work, and the type of ceramic restoration that we would remove. [1,2,4-6,11,12,16]

Another advantage was to use the Nd: YAG laser on the gingival tissue for a minor cosmetic gingivoplasty. The Nd: YAG laser promotes bleeding-free cutting $[17,18]$ with satisfactory tissue repair that allows impressions to be taken in the same session.

The Er: YAG laser, compared to the Er: CrYSGG, has a three times higher absorption in water, tissues and residual monomers, which results in the Er: YAG laser having a more superficial penetration, requiring less energy and time to perform the ablation of the cement in the interface between the ceramic restoration and the tooth, which will allow the removal process of the ceramic restoration to be carried out more quickly and to have a better control of the intrapulpal temperature. $[19,20]$

More well-designed controlled clinical trials and prospective longitudinal studies are needed to determine the precise laser parameters and duration of irradiation that could be used for the removal of ceramic restorations with different thickness.

\section{CONCLUSION}

The correct use of the high-power laser parameters (Er: YAG and Nd: YAG) and the use of the accompanying CAD / CAM technology, allowed this clinical case to be completed in a single visit without the use of temporary restorations. The results exceeded the patient's expectations aesthetically and emphasized the convenience of not having to spend weeks with temporary prostheses until returning to final cementation. After 1 year, the ceramics restorations were intact without any chipping or color change (Figures 8, 9).

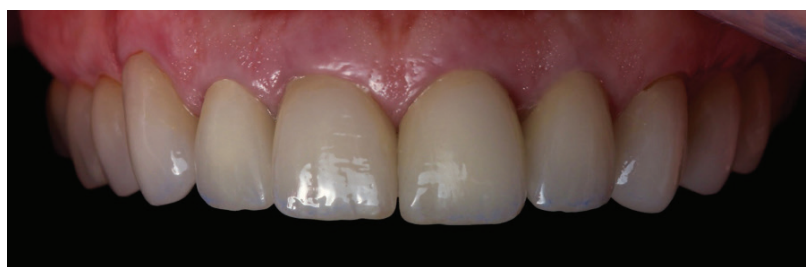

Figure 8 - After 1 Year.

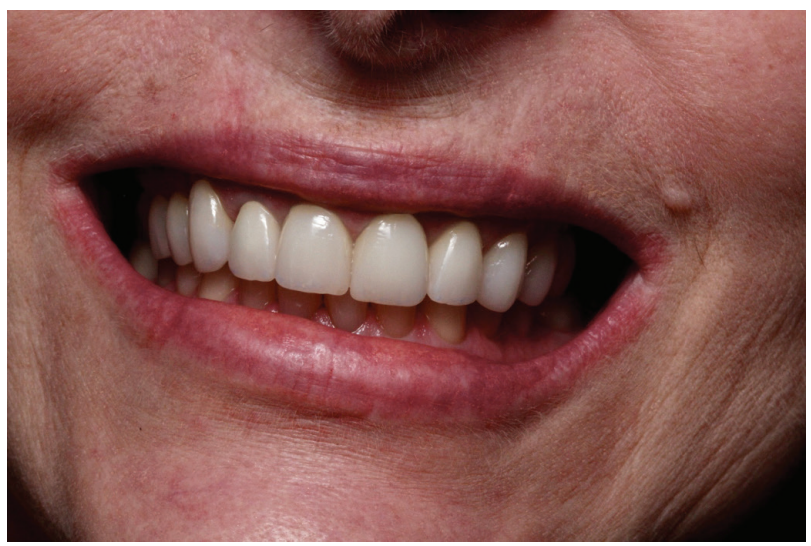

Figure 9 - After 1 Year.

\section{Declaration of Patient Consent}

The authors hereby declare that they have gathered all necessary consent forms from the patient showing his full authorization to use his images and further clinical information in the journal. The patient acknowledges that his name and initials will not be published publicly and extra efforts will be made to keep identities unknown. Nevertheless, this anonymity cannot be, by any chance, ensured.

\section{Author Disclosure Statement}

No competing financial interests exist.

\section{Acknowledgments}

The authors thank to prosthetic Anderson Alves for making ceramic prostheses, Patricia De Paula Eduardo for the supply of CAD/CAM equipment and Jorge Tafur for all help in this paper. 


\section{REFERENCES}

1. Karagoz-Yildirak M, Gozneli R. Evaluation of rebonding strengths of leucite and lithium disilicate veneers debonded with an Er:YAG laser. Lasers Med Sci. 2020;35(4):853-60. doi:101007/s10103-019-02872-8

2. Morford CK, Buu NC, Rechmann BM, Finzen FC, Sharma AB, Rechmann P.Er:YAG laser debonding of porcelain veneers. Lasers Surg Med. 2011;43(10):965-74. doi:10.1002//sm.21144

3. Gurney ML, Sharples SD, Phillips WB, Lee DJ. Using an Er,Cr:YSGG laser to remove lithium disilicate restorations: A pilot study. J Prosthet Dent. 2016 Jan;115(1):90-4.

4. Grzech-Leśniak K, Matys J,Żmuda-Stawowiak D, etal. Er:YAG Laser for Metal and Ceramic Bracket Debonding: An In Vitro Study on Intrapulpal Temperature, SEM, and EDS Analysis. Photomed Laser Surg. 2018;36(11):595-600. doi:10.1089/pho.2017.4412

5. Rechmann P, Buu NC, Rechmann BM, Le CQ, Finzen FC, Featherstone JD. Laser all-ceramic crown removal-a laboratory proof-of-principle studyphase 1material characteristics. Lasers Surg Med. 2014 0ct;46(8):628-35. doi: 10.1002/lsm.22279.

6. Sari T, Tuncel I,Usumez A, Gutknecht N. Transmission of Er: YAG laser through different dental ceramics. Photomed Laser Surg. 2014;32:37-41

7. Bayazit EÖ, Karabıyik M. Chairside restorations of maxillary anterior teeth with CAD/CAM porcelain laminate veneers produced by digital workflow: a case report with a step to facilitate restoration design. Case Rep Dent. 2019 Apr 4;2019:6731905

8. de Siqueira F, Cardenas A, Gruber YL, et al. Using CAD/CAM-Modified Correlation Mode to Produce Laminate Veneers: A Six-Month Case Report. Oper Dent. 2017;42(5):E139-E147.

9. Spitznagel FA, Boldt J, Gierthmuehlen PC. CAD/CAM Ceramic Restorative Materials for Natural Teeth. J Dent Res. 2018;97(10):1082-91. doi:10.1177/0022034518779759
10. Seydler B, Schmitter M. Clinical performance of two different CAD/CAMfabricated ceramic crowns: 2-Year results. J Prosthet Dent. 2015;114(2):212-6.

11. Saavedra G, Viegas DMDCP, CostaF, Kano P.Biological Restorations: a foreseeable possibility in the junction between dentistry and technology. Braz Dent Sci 2019 Jul/Set;22(3)

12. Kursoglu P, Gursoy H. Removal of fractured laminate veneers with Er:YAG laser: report of two cases. Photomed Laser Surg. 2013;31(1):41-43.

13. Zhang Y, Rocca JP,Fornaini C, Zhen Y, Zhao Z, Merigo E. Erbium-Doped, Yttrium-Aluminum-Garnet Laser Debonding of Porcelain Laminate Veneers: An Ex vivo Study. Contemp Clin Dent. 2018;9(4):570-3.

14. Sá TCM, de Carvalho MFF, de Sá JCM, Magalhães CS, Moreira AN, Yamaut M. Esthetic rehabilitation of anterior teeth with different thicknesses of porcelain laminate veneers: An 8-year follow-up clinical evaluation. Eur J Dent. 2018;12(4):590-3.

15. Blatz MB, Vonderheide M, Conejo J. The Effect of Resin Bonding on LongTerm Success of High-Strength Ceramics. J Dent Res. 2018;97(2):132-9.

16. Kellesarian SV, Ros Malignaggi V, Aldosary KM, Javed F.Laser-assisted removal of all ceramic fixed dental prostheses: A comprehensive review. J Esthet Restor Dent. 2018 May;30(3):216-22.

17. Inchingolo F, Tatullo M, Abenavoli FM, Marrelli M, Inchingolo AD, Inchingolo AM. Comparison between traditional surgery, CO2 and Nd:YAG laser treatment for generalized gingival hyperplasia in Sturge-Weber syndrome: a retrospective study. J Investig Clin Dent. 2010 Nov;(2):85-9.

18. Fornaini C, Rocca JP, Bertrand MF, Merigo E, Nammour S, Vescovi P.Nd:YAG and diode laser in the surgical management of soft tissues related to orthodontic treatment. Photomed Laser Surg. 2007;25(5):381-92.

19. Alikhasi M, Monzavi A, Ebrahimi H, Pirmoradian M, Shamshiri A, Ghazanfari R. Debonding time and dental pulp temperature with the Er, Cr: YSGG laser for debonding feldespathic and lithium disilicate veneers. J Lasers Med Sci. 2019;10(3):211-4.

20. Mirhashemi A, Chiniforush N, Jadidi H, Sharifi N. Comparative study of the effect of Er:YAG and Er:Cr;YSGG lasers on porcelain: etching for the bonding of orthodontic brackets. Lasers Med Sci. 2018;33(9):1997-2005.

\section{Christian Giancarlo Bernal Rodriguez}

